\title{
SUPPORT MEASURES AND THEIR IMPLEMENTATION AS A PART OF EDUCATION OF INDIVIDUALS WITH THE SPECIAL NEEDS
}

\author{
Barbora Lanková ${ }^{1}$, Michal Vostrý $^{1}$, Ladislav Zilcher $^{1}$, Tereza Landová $^{1}$ \\ ${ }^{1}$ Univerzity of Jan Evangelista Purkyně in Ústí nad Labem, Czech Republic
}

\author{
Eduport 5 (2) - Reviewed Papers \\ DOI: 10.21062/edp.2021.007
}

\begin{abstract}
Both planned and already implemented changes in legislation require even more complex competences while working with the pupils with support measures. It is required to work with the support measures and to be able to work with diverse methods or forms of tuition in a suitable manner for (if possible) all pupils. That is why it is imperative for all pedagogues to know, how to work effectively with these pupils and which methods and approaches to use during the education. Even though this problematic is not new, we can still meet pedagogues in praxis, who do not guide themselves in a correct manner while working with pupils with special needs. This fact is reflected in various studies, that served as an inspiration for our work. Submitted preliminary research maps the knowledge of pedagogues in use of correct methods and approaches based on the support measures. By using the questionnaire of our design, that reflected mainly the information found inside the Catalogue of Support Measures, we gathered data indicating the possible difference in work of pedagogues working with the pupils with special needs based on the type of school and length of their praxis in education.
\end{abstract}

Keywords: Specific learning disabilities, support, primary school, special education

\section{INTRODUCTION}

The objective of this contribution is to highlight the use of support measures in the education of pupils with specific learning disabilities. In the connection with the ever-accelerating development of our society, the emphasis on education is also increasing, which may be a certain reason why the importance of the issue of the SLD continues to grow (NPI, 2017a). Diagnosis of the SLD is most commonly carried out with pupils at the first level of primary school (mainly during the $2^{\text {nd }}, 3^{\text {rd }}$ and $4^{\text {th }}$ grade) and the appropriateness of diagnosis or its correct timing is still debated. In this respect, foreign authors often direct their attention to the pre-school age and the beginning of primary school (Zapletalová, Mrázková, 2014). In general, however, it is important to keep in mind that the teacher plays a key role, not only in the initial screening, as the teacher is also one of the important external factors influencing the overall manifestations of pupils with the SLD related to their current performance (NPI, 2017b). In particular, we are talking about the teacher's competencies for educating pupils with theSLD, as there is evidence that the higher the teacher's competencies in inclusive education, the higher the pupils' achievement (Pit-ten Cate et al., 2018). We also talk about how a teacher can effectively assess individual work with a pupil in relation to their specific needs (Halilu, Ahmed, 2020), how they can motivate, as appropriate motivation is the way to success (Krejčová et al., 2017; Louick, 2021), how they can organise work with a team, etc. However, a teacher's job is to some extent influenced by a number of aspects ranging from the number of pupils in the class, the length of teaching experience, the field of study that the teacher has studied to the type of primary school (urban/rural).

\section{THE CURRENT STATE OF KNOWLEDGE}

Currently, approximately 3-4\% of individuals with one of the specific learning disabilities attend an ordinary primary school (Ministry of Education, Youth and Sports 2021, Bartoňová, 2019). The specific learning disabilities are a group of neurodevelopmental disorders characterised by significant and persistent difficulties 
in learning, i.e., in the area of study skills, which may include reading, writing or arithmetic (Matteucci, Soncini, 2021). The prefix dis- refers to the lack or incorrect development of a skill, while the other part of the term, which is adopted from Greek, refers to the skill that is affected (Zelinková, 2015). The basic types of the SLD include dyslexia (reading disorder), dysorthography (spelling disorder), dysgraphia (graphic disorder) and dyscalculia (mathematical disorder) (Jucovičová, 2014). These types are also discussed abroad. On the other hand, the other types, including dyspraxia (developmental disorder of motor coordination), dyspinxia (drawing disorder), and dysmusia (disorder in acquiring musical skills), are more typical for the Czech environment (Pokorná, 2010). The types of the SLU mentioned above can be observed in pupils separately, but more often they are rather complex disorders (usually dyslexia, dysgraphia, dysortography). At the same time, some of the disorders can occur hand in hand with specific behavioural disorders (Jucovičová, Žáčková, 2020). In the Czech Republic, pupils with the SLU fall under the category of persons with disabilities in the legislation. However, it is important that in recent years these pupils have been referred to as pupils with special educational needs, which, according to Jucovičová and Žáčková (2014), describes them much better, as for these pupils not only re-education of their disorders is necessary, but also adaptation to them with the help of other teaching methods, special aids and evaluation methods. The specific learning disabilities refer to the specific errors that a pupil makes in school. These specific errors are different from non-specific difficulties that can be remedied by, for example, making the child read, count, write or paint more often. Specific difficulties do not disappear easily and therefore specific forms of re-education are needed to overcome the SLD, including teamwork between the family, the school and the counselling institution. At the first level of primary school, approaches and methods of remediation characteristic of individual manifestations of specific learning disabilities are used for re-education (Bartoňová, 2019).

Educating pupils with specific needs is governed by several legislative documents. The primary one is Act No. 561/2004 Coll., on pre-school, primary, secondary, vocational and other education, the so-called Education Act, which has been amended by Amendment No. 82/2015 Coll. The key section of this Act is Section 16 , which is dedicated to supporting the education of children, pupils and students with special educational needs (SEN), which includes even the specific learning disabilities. The term pupil with special educational needs is defined in Act No. 82/2015 Coll., Section 16 as follows: "A child, pupil and student with special educational needs is a person who needs the provision of support measures in order to fulfil their educational potential or to exercise or enjoy their rights on an equal basis with others." Support measures (abbreviated SM) include necessary adjustments in education and school services according to the individual needs of the child, pupil or student. Similarly, a child, pupil or student with special educational needs is entitled to the provision of these support measures free of charge by the school and the school institution. The support measures are further described in Decree No. 27/2016 Coll. (newly amended according to Decree No. 606/2020), which specifically regulates the rules for the education of children, pupils and students (hereinafter referred to as "pupils") with the SEN and gifted pupils. The support measures according to Act No. 82/2015 Coll. include, for example, counselling assistance of a school and educational institution, modification of the organisation, content, evaluation, forms and methods of education and school services, modification of the conditions of admission to education and termination of education, use of compensatory aids, special textbooks and special teaching aids, education according to an individual education plan (IEP), teacher's assistant and others. Pupils with specific learning disabilities are most often granted first to third level support measures (Bartoňová, 2019). In the year 2015, Catalogues of Support Measures were also created to "provide educational staff with a comprehensive manual of available support for children, pupils and students (hereinafter referred to as "pupils") with special educational needs" (Michalík, Baslerová, Felcmanová et al., 2015). Although the Catalogue of Support Measures for Pupils with the SLD was not published this year. It was published in the year 2020. Nevertheless, there are a number of materials available for teachers (cf. Zelinková, 2015; Jucovičová, Žáčková, 2015; Michalová, 2016; Jucovičová, Žáčková, 2016; Krejčová et al., 2017; Krejčová, Hladíková, 2019).

\section{METHOD}

The presented preliminary research is quantitatively oriented. Due to the closure of all schools in the Czech Republic due to the COVID-19 pandemic, when all students and teachers were educated at a distance, an online questionnaire survey was chosen using a Google form. We consider the questionnaire to be a suitable instrument, as the aim was to obtain, by mass collection, the largest possible set of research data, for which, also according to Doulik (2016), this instrument is suitable. We conducted the questionnaire survey during April 2021 until the end of May 2021. We constructed the questionnaire ourselves. It consists of a total of 26 questions. All formalities are included in the introduction (they included informed consent and anonymity information). The following questions number 1-6 concern general information about the 
respondents/pedagogues (type of primary school, number of years of teaching experience, etc.). This general part is followed by key questions 7-26, which are based on the study of the Catalogues of support measures $(2015 ; 2020)$ for pupils with the SEN. In particular, 10 questions concern support measures for pupils with learning disabilities and 10 questions focus on support measures for pupils with learning disabilities or autism spectrum disorders or selected mental illnesses. The questions were then divided into questionnaires so that they did not form thematic units. (The SM for pupils with the SLD - questions 7, 10, 11, 12, 16, 18, 21, 22, 24, 26; the SM for pupils with MI and ASD - 8, 9, 13, 14, 15, 17, 19, 20, 23, 25). At the same time, an important aspect for us was to formulate the questions in such a way that the teachers did not feel like they were being tested, but gave the impression that we were only asking for their opinion (e.g., If I have a dyslexic pupil in my class, I will regularly challenge him to read aloud). For each statement, teachers could respond on a scale based on how much they agreed or disagreed with the statement (strongly disagree; disagree; rather disagree; rather agree; agree; strongly agree). The method of "scaling" was chosen as it is through scaling that "we can generally capture a qualitative phenomenon in a quantitative form", but it is important that "each level of the scale is meaningful" (Rod, 2012, p. 7). Although we often encounter scales with an even number of items that additionally contain a neutral element, we have used for our purposes a scale with an even number of items and no neutral element which, for example, according to Clason and Dormody (1994) and Jamieson (2004), is also possible. In developing the scale in question, we followed the following four steps: understanding the given field, developing and rating the items under consideration, designing and implementing scale testing studies, and creating the scale (Netemeyer, Bearden, \& Sharma, 2003).

For the subsequent statistical data processing (descriptive/inductive), numerical values were assigned to each point on the scale (1- strongly disagree; 2- disagree; 3- rather disagree; 4- rather agree; 5- agree; 6- strongly agree). At the same time, we also created individual categories for other independent variables which include the length of practice (5 years and less; 6-10 years; $11-20$ years; more than 20 years) and the studied field (teaching of the first level of primary school; teaching of the first level of primary school with special pedagogy; special pedagogy; other field of study).

\section{RESULTS}

The research sample, in compliance with our aim, consisted of first grade teachers in both urban and rural primary schools. The questionnaire was sent to a total of 88 primary schools in the Ústí nad Labem Region. The districts were: Litoměřice, Ústí nad Labem, Teplice and Louny (49 urban and 39 rural primary schools). The return rate of questionnaires was low, which we attribute to the use of the online data collection method and the COVID-19 pandemic. We received 90 completed questionnaires, of which we had to discard three because they did not meet all the conditions. From the urban-type primary school, 59 teachers (five of whom were male) responded, and from the rural-type school, 28 teachers (one of whom was male) responded. The majority of teachers had teaching experience of more than 20 years ( 42 teachers) and the number of pupils was mostly between 22 and 28 per class.

In compliance with the objective of our preliminary research, we determined three basic research problems: How does the type of primary school affect teachers' attitude towards pupils with the SLD? (RP1); What is the effect of length of teaching experience on teachers' attitude towards pupils with the SLU? (RP2); What is the effect of the field of study on teachers' attitude towards pupils with the SLU? (RP3). With a research problem defined in this way, we need to specify what we mean by the use of the term attitude. In our case, the word attitude is understood in the sense of the use of elements of support measures in the teaching of pupils with the SLU at the first grade of primary school.

\section{Descriptive statistics}

Descriptive statistics and its variables in compliance with Hendel (2012): frequency (N), average, average value $(\varnothing)$, median (Me), mode (Mod), minimum (Min), maximum (Max), standard deviation (SD) (table 1).

Table 1 Basic descriptive data for the whole research set depending on the individual questions

\begin{tabular}{ccccccc}
\hline & $\varnothing$ & Me & Mod & SD & Max & Min \\
\hline Q1 & 4.19 & 5 & 5 & 1.46 & 6 & 1 \\
\hline Q2 & 1.57 & 1 & 1 & 1.13 & 6 & 1 \\
\hline Q3 & 2.94 & 3 & 2 & 1.6 & 6 & 1 \\
\hline
\end{tabular}




\begin{tabular}{ccccccc}
\hline Q4 & 4.88 & 0 & 6 & 1.32 & 6 & 1 \\
\hline Q5 & 2.58 & 2 & 1 & 1.74 & 6 & 1 \\
\hline Q6 & 2.33 & 2 & 2 & 1.2 & 5 & 1 \\
\hline Q7 & 1.35 & 1 & 1 & 0.9 & 6 & 1 \\
\hline Q8 & 3.27 & 3 & 3 & 1.61 & 6 & 1 \\
\hline Q9 & 3.96 & 4 & 4 & 1.3 & 6 & 1 \\
\hline Q10 & 5.85 & 6 & 6 & 0.42 & 6 & 4 \\
\hline Q11 & 5.25 & 6 & 6 & 1.2 & 6 & 1 \\
\hline Q12 & 5.38 & 6 & 6 & 1.01 & 6 & 1 \\
\hline Q13 & 3.79 & 4 & 4 & 1.55 & 6 & 1 \\
\hline Q14 & 3.54 & 4 & 4 & 1.61 & 6 & 1 \\
\hline Q15 & 2.55 & 2 & 1 & 1.54 & 6 & 1 \\
\hline Q16 & 3.9 & 4 & 4 & 1.36 & 6 & 1 \\
\hline Q17 & 3.71 & 4 & 3 & 1.28 & 6 & 1 \\
\hline Q18 & 1.53 & 1 & 1 & 1.1 & 6 & 1 \\
\hline Q19 & 3.15 & 3 & 3 & 1.62 & 6 & 1 \\
\hline Q20 & 3.95 & 4 & 6 & 1.54 & 6 & 1 \\
\hline
\end{tabular}

\section{Inductive statistics}

Within the framework of inductive statistics, we first verified the normality of the data and then, using appropriately chosen statistical methods, we investigated the dependence of individual variables, which we also graphically represented. Since in neither case will the Shapiro-Wilk test result in a comparison of sets that have only a normal distribution of frequencies, we decided to continue to use non-parametric statistical tests. We used the Mann Whitney $U$ test to test the first hypothesis regarding the effect of the type of primary school on teachers' attitude towards the SLD. As the other two cases involved comparing more than two independent sets, the Kruskal-Wallisanova was still chosen to implement inductive statistics in this regard.

In the first case, we focus on the effect of the type of primary school on teachers' attitude towards pupils with the SLD. However, the test results show no statistically significant association between the type of primary school and teachers' attitude towards pupils with the SLD $(p=.1649)$. 
Chart 1 Influence of the type of primary school on teachers' attitude towards pupils with the SLD

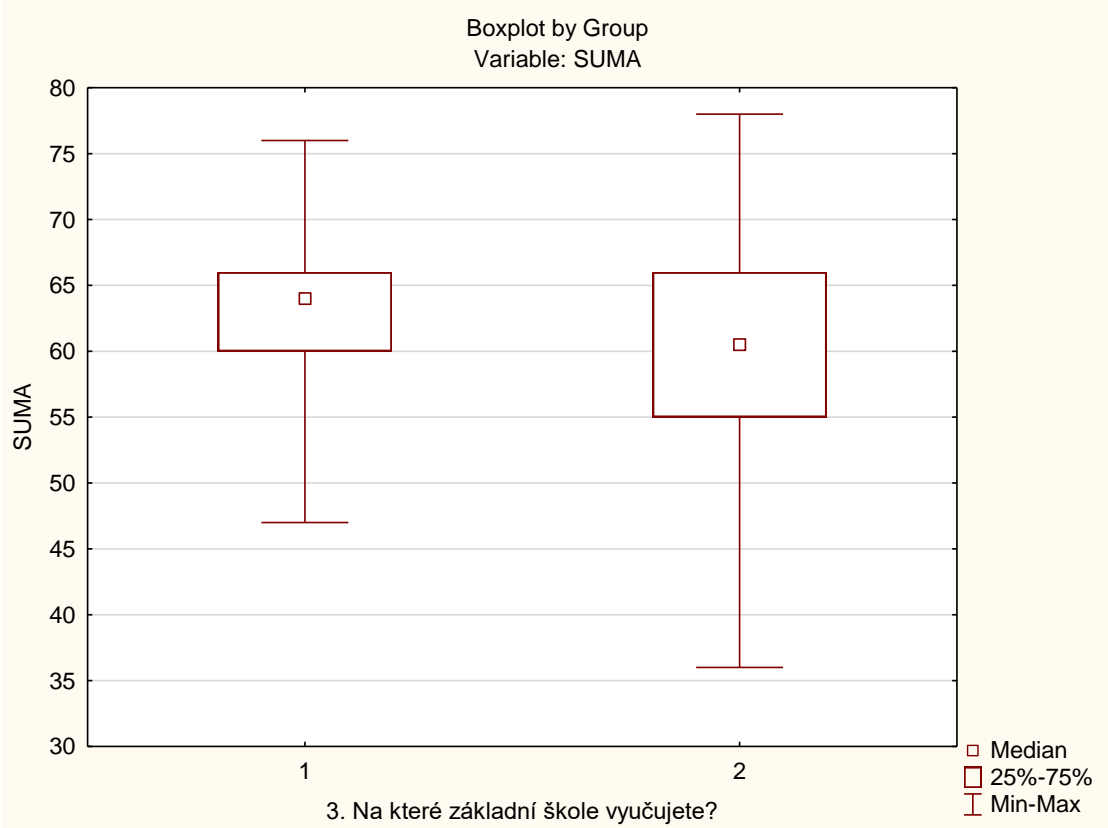

Even in the second case, in which the effect of the length of teaching experience on teachers' attitude towards pupils with the SLD was investigated, there was no statistically significant effect depending on the variables $(p=.8199)$.

Chart 2 Effect of teaching experience on teachers' attitude towards pupils with the SLD

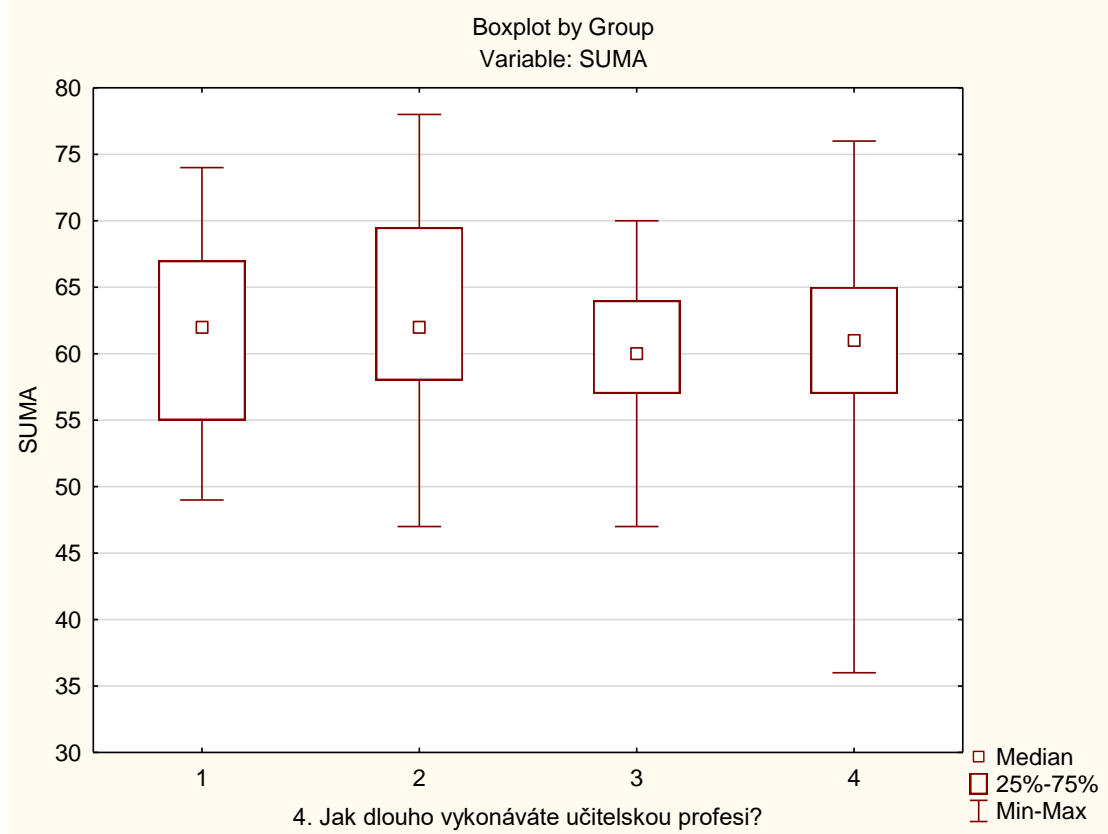

In the last chart (chart 3), there is displayed the effect of the studied degree on teachers' attitude towards pupils with the SLD. Here the $p$ level value was only slightly different from the previous cases $(p=.2563)$, and even here we cannot accept the alternative hypothesis confirming the effect of both variables. The description and visualization displayed interesting differences, yet these differences, given the results of the inductive statistics, cannot be considered statistically significant. 
Chart 3 The effect of the studied degree on teachers' attitude towards pupils with the SLD

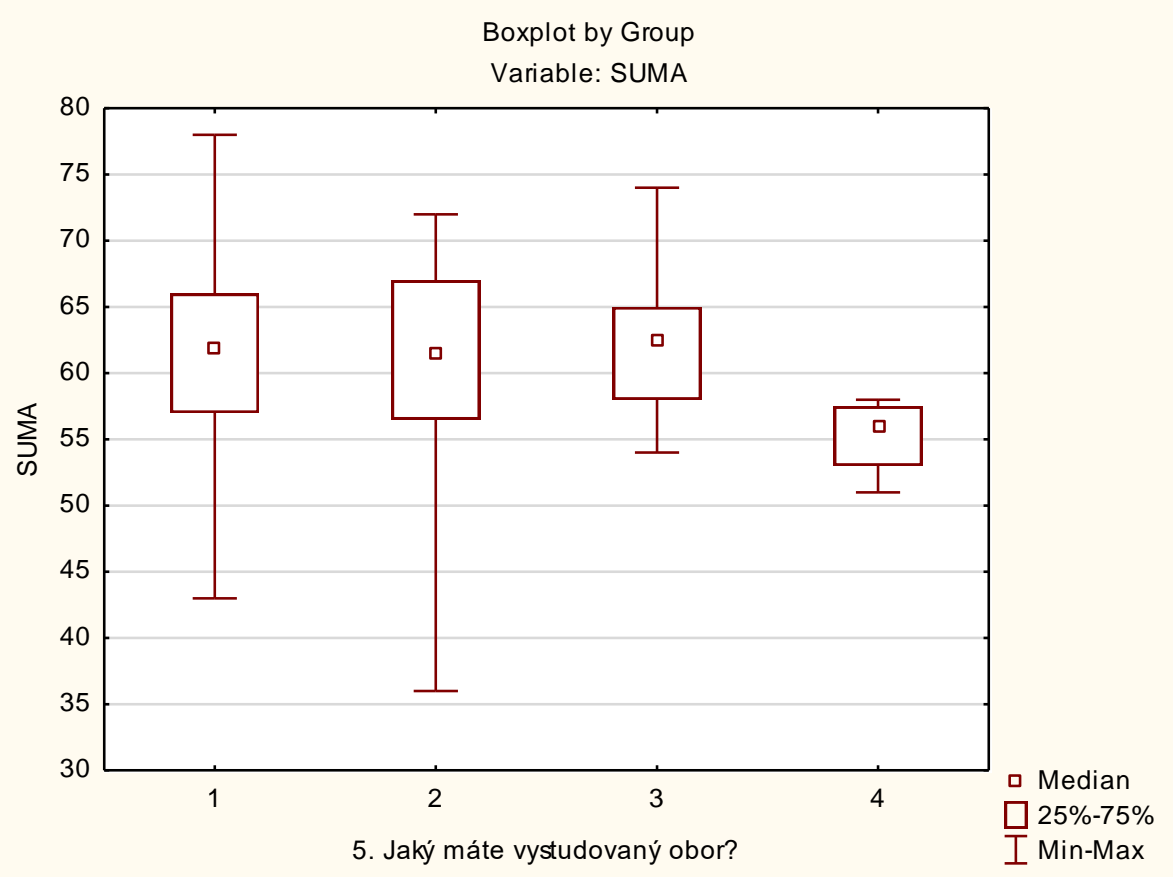

\section{DISCUSSION}

Within the framework of our contribution, we have drawn on two studies. Firstly, there was a study in which the authors investigated whether there was any relationship between the length of teaching experience and teachers' current knowledge about the SLD (Michalová et al., 2012). Just as in our case, there was no effect of the length of teaching experience on teachers' attitude towards pupils with the SLD $(p=.8199)$, there was no significant association between the length of teaching experience and teachers' current knowledge of the SLD issues in the study by the aforementioned authors. The question here is whether this is a favourable indicator, as a more professional approach can be expected from teachers who have more years of teaching experience. After all, in foreign countries, the number of years of experience is related to the teacher's pedagogical quality, acquired competences, etc., for example in Australia (novice, competent, outstanding, leader) (Tomková et al., 2012). In addition, many countries consider the completion of teacher education and continuous development as an essential part of the teaching profession (Darling-Hammond, 2017). This led us to another thought, namely whether a teacher's degree has an impact on teachers' attitude towards pupils with the SLD. No statistically significant dependence was found in this case either. Here is also room for pause and reflection, for the question is whether special teachers should not in some way overshadow teachers without special education in this issue? On the other hand, it is true that a significant number of teachers would welcome a special teacher in the primary school to support them in the education of pupils with the SEN. This fact is confirmed by the research of Kř́ž et al. (2021), in which $90.1 \%$ of the teachers surveyed $(N=615)$ unanimously agreed on the need for support from a school-based special educator. As a follow-up to the above, and to the general concept of individual approaches to pupils in general, there is also the fact that in the Czech Republic in the year 2018, the average number of pupils per teacher in primary school was 19.8, while in the European Union only Romania had such a high number in the same year (eurostat, 2020). It is not surprising, then, that the phenomenon of rural schools is making a comeback, with parents starting to target their children for primary education in rural-type schools. The strength of small schools, due to the small number of pupils, is the possibility to give almost every pupil full individual attention (Ađalsteinsdóttir, 2004). Here, we come to our last question, which was whether the type of primary school has an effect on the teachers' attitude towards pupils with the SLD. Looking at the Chart 1, we see a slight difference in favour of rural schools, but this was not specifically significant $(p=.1649)$. In the context of descriptive statistics, it is in some cases alarming that 
teacher did not indicate clear disagreement or agreement with the given statement. For example, for question number five, when teachers were asked to respond to the statement "if I have a pupil with the SLD in my class, I can evaluate him with a grade 5, even if the errors are related to their specific educational needs" with a clear disagreement, i.e., around the value of 1 , the average value was around 2.53 . Similarly, when teachers were asked whether a pupil with the SLD should be assessed preferably with a mark and a verbal assessment, we expected a clear agree answer (around value 6), but this did not happen and respondents' answers ranged sometimes between the points rather disagree/rather agree. The last and perhaps most surprising value for us was recorded for question 11, when we asked teachers whether expected outcomes could be modified for pupils with the SLD. Here, the teachers' responses ranged on average between agree/ strongly agree (5.25). In general, as the descriptions show, it is quite important that teachers are not very confident about the support and work with pupils with the SLD. Meanwhile, research by Kř́ž et al. (2021) suggests that $76.6 \%$ of all teachers surveyed feel prepared to work with these pupils. On the other hand, it is crucial not only that teachers feel prepared, but more importantly that all teachers are able to work effectively with these pupils. It is important that the teacher is able to identify the specific learning difficulties early on, the earlier the more scope there is for positively influencing the learning progress of pupils with the SLD and creating more opportunities for them to experience success (Hinton, 2006). It is still essential that teachers use appropriate and activating strategies to motivate these pupils and develop their self-esteem, as research shows that this approach is much more effective than the transmissive approach to teaching (Bishara, Wubbena, 2018). Therefore, it is more than desirable for every teacher to be sufficiently educated in the effective education of pupils with the SLD (Halilu, Ahmed, 2020).

\section{CONLUSION}

The presented preliminary research aimed to investigate the influence of partial aspects on the teacher's attitude towards pupils with the specific learning disabilities. Within the framework of the preliminary research, there was created an instrument (questionnaire), which consisted of statements emerging from the Catalogues of support measures. Using the developed six-point scale, the teacher then rated whether they agree that the support measure was appropriate for pupils with the specific learning difficulties. Three aspects, namely length of teaching experience, studied degree and the type of primary school, were chosen as independent variables based on the existing research. The results of the inductive statistics did not show statistically significant values at the $5 \%$ level of significance in any of the cases and thus it was not possible to accept the alternative hypothesis in any of the cases. Minor nuances can be observed in Charts 1-3, but in none of the cases can they be considered significant, based on what has already been mentioned. A more interesting presentation of the results is offered by the descriptive statistics, which point to the fact that teachers are not entirely confident in their use of each measure. However, if we focus on the intervening variables, it is necessary to mention possible aspects influencing the results obtained. Primarily, it is important to take into account the following: data collection took place online and especially during the pandemic period (a); the sample of respondents is not large and therefore the results cannot be generalized (b); each pupil must be approached individually, therefore some measures, seemingly inappropriate, may suit even one pupil (c); schools were contacted only in the Ústí nad Labem Region (d); the number of teachers from rural schools did not account for even half of the respondents (e). The task of the preliminary research was to further verify the developed instrument (questionnaire) and the clarity of its assignment and formulation. None of the teachers indicated that any of the items were incomprehensible to them or that they did not know how to complete the questionnaire. In the next, upcoming survey, a much larger number of primary schools will be approached across the individual regions (schools will be selected on the basis of set criteria). Among other things, attention will also be directed to the number of pupils with the SLD in the classroom, as well as to cooperation with parents and counselling departments. At the same time, there is room for double verification, where pupils with the SLD would be approached to determine the level of motivation and self-concept, following the answers of individual teachers in the questionnaire we have created. One possibility would also be to investigate the extent to which the attitude towards pupils with the SLD differs between teachers at the first and second level.

\section{Acknowledgements}

This paper has been written with the support of an internal grant at Pedagogical Faculty.

References 
[1] Jamieson, S. (2004). Likert scales: How to (ab)use them. Medical Education, 38, 1212-1218.

[2] Clason, D. L. \& Dormody, T. J. (1994). Analyzing data measured by individual Likert-type items. Journal of Agricultural Education, 35(4), 31-35.

[3] Rod, A. (2012). Likertovo škálování. E-Logos Electronic Journal for Philosophy, 13, 2-14.

[4] Netemeyer, R. G., Bearden, W. O., \& Sharma, S. (2003). Scaling procedures: Issues and applications. Sage Publications.

[5] Krejčová, L, \& Hladíková, Z. (2019). Zvládáme specifické poruchy učení: dyslexie, dysortografie, dysgrafie. Edika.

[6] Krejčová, L., Zelinková, O., Balharová, K. et al. (2017). Specifické poruchy učení: dyslexie, dysgrafie, dysortografie. Edika.

[7] Jucovičová, D, \& Žáčková, H. (2017). Školní hodnocení a žáci se specifickými poruchami učení a chování: (využitelné pro základní i střední školy). D + H.

[8] Jucovičová, D., Žáčková, H. (2015). Jak se učit s dítětem se specifickou poruchou učení a s poruchou pozornosti?: určeno žákům a studentům se specifickými poruchami učení a s poruchou pozornosti a jejich rodičům a učitelům. $\mathrm{D}+\mathrm{H}$.

[9] Darling-Hammond, L. (2017). Teacher education around the world: What can we learn from international practice? European Journal of Teacher Education, 40(3), 291309. https://doi.org/10.1080/02619768.2017.1315399

[10] Ađalsteinsdóttir, K. (2004). Teachers' behaviour and practices in the classroom. Scandinavian Journal of Educational Research, 48(1), 95-13. https://doi.org/10.1080/0031383032000149869

[11] Louick, R., \& Muenks, K. (2021). Leveraging Motivation Theory for Research and Practice with Students with Learning Disabilities. Theory Into Practice. https://doi.org/10.1080/00405841.2021.1932154

[12] Michalová, Z. (2016). Specifické poruchy učení. Tobiáš.

[13] Zelinková, O. (2015). Poruchy učení: dyslexie, dysgrafie, dysortografie, dyskalkulie, dyspraxie, ADHD. Portál.

[14] Pit-ten Cate, I. M., Markova, M., Krischler, M., \& Krolak-Schwerdt, S. (2018). Promoting Inclusive Education: The Role of Teachers' Competence and Attitudes. Insights into Learning Disabilities, 15(1), 4963.

[15] Eurostat (2020). Pupils per teacher in EU primary schools. https://ec.europa.eu/eurostat/web/productseurostat-news/-/DDN-20200909-1?inheritRedirect=true\&redirect=\%2Feurostat\%2Fhome\%3F

[16] Halilu, M., \& Ahmed, S. (2020). Overcoming Learning Disabilities among Children in Primary Schools. International Journal of Education and Evaluation, 6(2), 1-5.

[17] Bishara, S., \& Wubbena, Z. (2018). Active and traditional teaching, self-image, and motivation in learning math among pupils with learning disabilities. Cogent Education, 5(1), 1436123.10.1080/2331186X.2018.1436123

[18] Mrázková, J., \& Zapletalová, J. (2014). Metodika pro nastavování podpưrných opatření ve školách ve spolupráci se školskými poradenskými zařizeními. Národní ústav pro vzdělávání.

[19] Hinton, C. D. (2006). Brain and learning: Dyslexia primer. https://www.oecd.org/education/ceri/primerondyslexia.htm

[20] Michalová, Z., Pešatová, I., Beránková, I., Dražilová, L., \& Havlová, D. (2012). Připravenost učitelů na inkluzivní vzdělávání $v \quad$ oblasti specifických poruch učení.

[21] Rod, A. (2012). Likertovo škálování. E-Logos Electronic Journal for Philosophy, 13, 2-14. http://elogos.vse.cz/pdfs/elg/2012/01/13.pdf

[22] Kř́iž, J., Svoboda, Z., Veteška, J., Volfová, K., Zilcher, L. (2021). Edukace jako nástroj prevence sociální exkluze $v$ Ústeckém kraji. Česká andragogická společnost.

[23] Tomková, A., Spilková, V., Píšová, M., Mazáčová, N., Krčmářová, T., Kostková, K., \& Kargerová, J. (2012). Rámec profesních kvalit učitele. Hodnoticí a sebehodnoticí arch. Národní ústav pro vzdělávání, školské poradenské zařizení a zařizení pro dalši vzdělávání pedagogických pracovníků.

[24] NPI. (2017a). Základní informace o specifických poruchách učení. https://digifolio.rvp.cz/view/view.php?id=13017

[25] NPI. (2017b). Intervence a podpora žáků s SPU při společném vzdělávání. https://digifolio.rvp.cz/view/view.php?id=13018

[26] Vyhláška č. 27/2016 sb., o vzdělávání žáků se speciálními vzdělávacími potřebami a žáků nadaných. https://www.zakonyprolidi.cz/cs/2016-27/zneni-20210101

[27] Zákon č. 82/2015 Sb., o predškolním, základním, středním, vyšším odborném a jiném vzdělávání. https://www.zakonyprolidi.cz/cs/2015-82 
[28] Zákon č. 561/2004 Sb., o předškolním, základním, středním, vyšším odborném a jiném vzdělávání. http://zakony.centrum.cz/skolsky-zakon/cast-1

[29] Vyhláška 606/2020 Sb., kterou se mění vyhláška č. 27/2016 Sb., o vzdělávání žáků se speciálními vzdělávacími potřebami a žáků nadaných, ve znění pozdějších předpisů. https://www.zakonyprolidi.cz/cs/2020-606

[30] Doulík, P. (2016). Vybrané základy metodologie pedagogického výzkumu (se cvičeními). PF UJEP.

[31] Bartoňová, M. (2019). Specifické poruchy učení a chování: Distanční studijní text [online]. https://www.slu.cz/file/cul/f33cf116-a5c3-40e9-97cf-38c012cc7ffa

[32] MŠMT. (2021). Statistická ročenka školství - výkonové ukazatele školního roku 2020/2021. https://statis.msmt.cz/rocenka/rocenka.asp

[33] Matteucci, M. C., \& Soncini, A. (2021). Self-efficacy and psychological well-being in a sample of Italian university students with and without Specific Learning Disorder. Research in Developmental Disabilities, 110, 103858. https://doi.org/10.1016/j.ridd.2021.103858

[34] Michalová, Z., Pešatová, I., Beránková, I., Dražilová, L., \& Havlová, D. (2012). Připravenost učitelů na inkluzivní vzdělávání $v \quad$ oblasti specifických poruch učení. http://dspace.specpeda.cz/bitstream/handle/0/150/30-45.pdf?sequence=1

[35] Katalog podpůrných opatření. (2015). Katalog podpůrných opatření pro žáky s potřebou podpory ve vzdělávání z důvodu zdravotního nebo sociálního znevýhodnění. http://katalogpo.upol.cz/

[36] Jucovičová, D., Žáčková, H. (2020). Katalog podpưrných opatření: dilčí část : pro žáky s potřebou podpory ve vzdělávání z důvodu specifických poruch učení a chování. Univerzita Palackého v Olomouci. 